\title{
Interactions Between Peptide and Preservatives: Effects on Peptide Self-Interactions and Antimicrobial Efficiency In Aqueous Multi-Dose Formulations
}

\author{
P. Heljo ${ }^{\text {I,4 }}$ • A. Ross ${ }^{2}$ •।. E. Zarraga ${ }^{3} \cdot$ A. Pappenberger ${ }^{\prime} \cdot$ H-C. Mahler ${ }^{\prime}$
}

Received: 2 February 2015 / Accepted: 13 April 2015 / Published online: 18 April 2015

(C) Springer Science+Business Media New York 2015

\begin{abstract}
Purpose Antimicrobial preservatives are known to interact with proteins and potentially affect their stability in aqueous solutions. In this systematic study, the interactions of a model peptide with three commonly used preservatives, benzyl alcohol, phenol and m-cresol, were evaluated.

Methods The impact on peptide oligomerization was studied using GC-MALS, SEC-MALS and DLS, antimicrobial efficiency of different formulations were studied using the $\mathrm{Ph}$. Eur. antimicrobial efficacy test, and the molecular adsorption of preservative molecules on reversible peptide oligomers was monitored using NMR.
\end{abstract}

Results The hydrodynamic radius and molar mass of the peptide oligomers was shown to clearly increase in the presence of m-cresol but less significantly with phenol and benzyl alcohol. The increase in size was most likely caused by peptide self-interactions becoming more attractive, leading to reversible oligomerization. On the other hand, increasing the concentration of peptide in multi-dose formulations led to

Electronic supplementary material The online version of this article (doi: 10. I007/s I | 095-0 I 5- |697-z) contains supplementary material, which is available to authorized users.

P. Heljo

petteri.heljo@roche.com

Pharmaceutical Development \& Supplies, Pharma Technical Development Biologics Europe (PTDE), F. Hoffmann - La Roche Ltd., Grenzacherstrasse I24, 4070 Basel, Switzerland

2 Discovery Technologies, Small Molecules Research (SMR), Pharma Research and Early Development (pRED), F. Hoffmann - La Roche Ltd., Basel, Switzerland

3 Late Stage Pharmaceutical Development, Genentech Inc., South San Francisco, California, USA

4 Division of Pharmaceutical Technology, Department of Pharmaceutical Sciences, University of Basel, Basel, Switzerland

reduced molecular mobility and decreased antimicrobial efficacy of all preservatives.

Conclusions Peptide-preservative interactions not only affect peptide self-interactions, but also antimicrobial efficiency of the preservatives and are thus of significant relevance. Adsorption of preservatives on oligomeric states of peptides is proposed as a mechanism to explain this reduced antimicrobial efficacy.

KEY WORDS antimicrobial efficacy · interaction .

oligomerization · peptide $\cdot$ preservative

\section{ABBREVIATIONS}

$\overline{\mathrm{M}}_{\mathrm{w}}$

$\overline{\mathrm{r}}_{\mathrm{H}}$

$\mathrm{A}_{2}$

AET

$\mathrm{C}_{0}$

CFU

CG-MALS

$\mathrm{C}_{\mathrm{i}}$

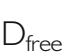

DLS

Dobs

DOSY

$D_{\text {pep }}$

$f$

$f_{s}$
Weight average molar mass

Hydrodynamic radius

Second virial coefficient

Antimicrobial efficacy testing

Preservative concentration required to

kill/inactivate all microbes in the

absence of peptide

Colony forming unit

Composition-gradient multi-angle

light scattering

Preservative concentration required to

kill/inactivate all microbes in the presence

of peptide

Preservative diffusion coefficient in the

absence of peptide

Dynamic light scattering

Preservative diffusion coefficient in the

presence of peptide

Diffusion ordered NMR spectroscopy

Peptide diffusion coefficient

Fraction of live microbes after incubation

Sequestered preservative fraction

(in AET experiments) 


\section{$M_{w} \quad$ Apparent molar mass \\ NMR Nuclear magnetic resonance \\ pl Isoelectric point \\ PON Octanol-water partition coefficient \\ $P_{\text {pep }} \quad$ Peptide-bound preservative fraction (in NMR experiments) \\ SEC-MALS Size-exclusion chromatography, coupled with multi-angle light scattering detector}

\section{INTRODUCTION}

Antimicrobial preservatives must be added to parenteral multi-dose formulations in order to inhibit the growth or kill or inactivate any microbes which may be inadvertently introduced into the drug product during repeated product use (1-3). Currently, the most commonly used preservatives in parenteral protein and peptide products are $\mathrm{m}$-cresol, phenol and benzyl alcohol (molecular structures shown in Fig. 1), whereas chlorobutanol and thiomersal (thimerosal) are less frequently used for various reasons (4).

One challenge often encountered when using antimicrobial preservatives in protein formulations is their potential impact on protein stability. Several examples can be found in literature where commonly used aromatic preservatives exhibit a negative effect on the physicochemical stability of proteins (e.g., 4-7). These preservative-protein interactions can lead to changes in protein conformation and increased aggregation tendency (5), decreased stability at higher temperatures $(6,7)$ and/or chemical modifications (8). Several studies comparing the effects of phenol, m-cresol and benzyl alcohol on protein stability have suggested that benzyl alcohol generally appears to cause fewer instability issues than phenol or $\mathrm{m}$ cresol $(6,7,9,10)$.

Different hypotheses have been proposed regarding the molecular mechanisms of interactions between proteins or peptides and preservatives. These include the preservatives forming hydrogen bonds with carbonyl and/or amide moieties of amino acid residues (5), their aromatic rings forming $\pi$ interactions and/or hydrophobic attractions with amino acids (11-13) and phenolic compounds oxidizing into quinones and subsequently covalently bonding with peptides as well as deprotonated preservatives forming ionic interactions with charged amino acid residues (14). As a number of groups

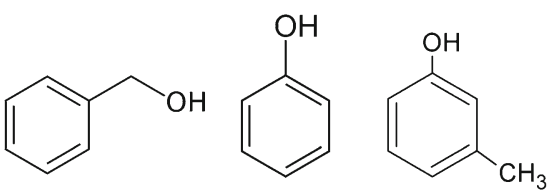

Fig. I Molecular structures of benzyl alcohol (left), phenol (center) and mcresol (right). conclude (e.g., 9, 11, 12), it is also likely that a combination of these mechanisms contribute to the interaction simultaneously. Overall, the intensity of interaction seems relatively weak $(9,15)$ and it is not limited to only certain interaction sites even though certain structural "hot-spots" in the peptide or protein may bind preservatives more strongly $(11,13)$.

It should be noted that preservative-polypeptide interactions do not always lead to unfavorable effects on API stability. Phenolic compounds have been shown to stabilize the $\mathrm{R}_{6}-\mathrm{Zn}$ insulin hexamer (11), which displays the highest physicochemical stability of the commonly manifesting Zn-insulin oligomers (16). Similarly, it has been postulated that benzyl alcohol stabilizes a partially unfolded state of lysozyme due to preferential interactions with that particular conformation, thus inhibiting its further conversion towards more aggregationprone states $(17,18)$. Data from our own group also shows that the addition of excipients which can act as preservatives can increase protein stability, for example by scavenging radicals and thus acting as antioxidants (unpublished results). In conclusion neither the interactions between a given preservative and a protein or peptide nor their practical consequences on API stability are easy to predict.

The purpose of this study was to explore the effects of three antimicrobial preservatives commonly used in parenteral products, benzyl alcohol, m-cresol and phenol, on the oligomerization state of a model peptide. Furthermore, the antimicrobial efficacy (i.e., microbial inactivation rates after inoculation with bacteria) of different formulations containing peptides and preservatives were compared in order to assess whether peptide/preservative interactions can have an effect on the antimicrobial efficacy of preservatives and thus on bacterial viability.

\section{MATERIALS AND METHODS}

\section{Peptides and Excipients}

The model peptide in the studies was provided by F. Hoffmann-La Roche Ltd. (Basel, Switzerland). The peptide $\left(\mathrm{M}_{\mathrm{w}} \sim 4.5 \mathrm{kDa}, 40\right.$ amino acid residues) was acylated with palmitoyl (C16) at the C-terminus. The peptide backbone contained 4 proline residues and 6 residues with aromatic side groups (including phenylalanine, tyrosine and tryptophan), and with an isoelectric point $(\mathrm{pI})$ of 3.2, its overall electrostatic charge was negative at $\mathrm{pH}$ 7.0. Peptide purity was $>95 \%$ and it was formulated in $20 \mathrm{mM}$ His/His-HCl buffer ( $\mathrm{pH} 7.0$ ) with $150 \mathrm{mM} \mathrm{NaCl}$. Under these formulation conditions the peptide manifests mainly as a pentamer, and the oligomeric state does not change measurably during 12 months of storage at either $2-8^{\circ} \mathrm{C}$ or $25^{\circ} \mathrm{C}$ (data not shown). To study whether the buffer composition affects preservative interaction tendency, the peptide was also formulated in $20 \mathrm{mM}$ Na-phosphate 
buffer (pH 7.0) with $130 \mathrm{mM} \mathrm{NaCl}$ in selected experiments. Benzyl alcohol (Ph. Eur. excipient grade, Merck KGaA, Darmstadt, Germany), m-cresol (Ph. Eur. excipient grade, Lanxess Deutschland GmbH, Leverkusen, Germany) and phenol (Ph. Eur. excipient grade, Merck KGaA, Darmstadt, Germany) were combined with the peptide formulations to produce different peptide/preservative mixing ratios. All formulations were manufactured in water for injections (WFI).

\section{Peptide-Preservative Assembly Size and Self-Interaction Tendency Measurement}

\section{CG-MALS}

The self-interactions of the peptide in the presence and absence of antimicrobial preservative were studied using composition-gradient multi-angle light scattering (CGMALS). The background of the analysis method has been comprehensively described by Some and Kendrick (19). Briefly, the excess Rayleigh scattering $\left(\mathrm{R}_{\mathrm{s}}-\mathrm{R}_{0}\right)$ of point-like, monodisperse and self-interaction-free polypeptide monomers can be used to calculate their molar mass according to the following equation:

$R_{s}-R_{0}=\frac{4 \pi^{2} n_{0}^{2}}{\mathcal{N}_{A} \lambda_{0}^{4}}\left(\frac{d n}{d c}\right)^{2} M c=K^{*} M c$

where $n_{0}$ is the refractive index of the solution, $\mathcal{N}_{A}$ is Avogadro's number, $\lambda_{0}$ is the wavelength of incident light in vacuum (here $659 \mathrm{~nm}$ ) and $d n / d c$ is the refractive index increment of the polypeptide (here 0.185$), M$ its molar mass and $c$ its concentration. The constant $K$ can be used to distill all other constants into a single term.

However, in real solutions the polypeptide monomers interact non-specifically with each other, leading to a deviation from the ideal relationship between excess Rayleigh scattering and concentration. This deviation can be taken into account by applying one or more virial expansion coefficients (i.e., $\mathrm{A}_{2}$, $\mathrm{A}_{3}$ etc.) to Eq. 1 as follows (19):

$\frac{K^{*} c}{R_{s}-R_{0}}=\frac{1}{\bar{M}_{w}}+2 A_{2} c+3 A_{3} c^{2}+\ldots$

It should be noted that since polypeptide self-interactions lead to an equilibrium state where several different oligomeric states exist simultaneously due to monomer association and dissociation, Eq. 2 now yields the weight average molar mass $\left(\bar{M}_{w}\right)$ of all oligomer units present in the solution. The virial coefficients can be used to draw conclusions regarding the nature of the self-interactions, where positive coefficient values indicate dominantly repulsive interactions and negative values dominantly attractive ones.
Concentration gradients of the model peptide were created using two of the three pumps of Calypso II system (Wyatt Technology Corporation, CA, USA), while using the third pump to vary the concentration of antimicrobial preservatives in the solution. The solutions were analyzed at $25^{\circ} \mathrm{C}$ with inline Optilab® rEX differential refractometer and DAWN ${ }^{\circledR}$ Heleos ${ }^{\circledR}$ II multi-angle light scattering (MALS) detector $\left(\mathrm{W}_{\mathrm{y}-}\right.$ att Technology Corporation, CA, USA), which measured simultaneously the light scattering intensity and refractive index of the solutions. The practical details of such measurements are described, for example, in Attri and Minton (20). 12 gradient steps (concatenated from two separate measurements) of the peptide at $0.17-10 \mathrm{mg} / \mathrm{ml}$ concentration range were used in the measurements, and these concentration gradients were produced while varying the antimicrobial preservative concentrations $(0,2,4,6,8$ or $10 \mathrm{mg} / \mathrm{ml})$ in formulation buffer. To take into account the effect of antimicrobial preservatives on the refractive index of the solution, the reference cell of the refractometer was flushed before each measurement with buffer containing an equal amount of preservative as in the peptide solution. All stock solutions were prefiltered through $0.1 \mu \mathrm{m}$ filters (Anotop, GE Healthcare AB, Uppsala, Sweden) before measurement.

Data procession was carried out using Calypso 2 software (Wyatt Technology Corporation, CA, USA). $\mathrm{A}_{2}$ values were calculated using Calypso 2 -software by assuming 5-mer as the main oligomer size (see Fig. 4 for the size-exclusion chromatography results which support this claim) and by plotting the data in reversible dimerization models (i.e., modeling for 5-mer / 10-mer equilibrium). This model was selected because its goodness of fit $\left(\chi^{2}\right)$ was low for all preservative concentrations and the model was relatively simple. On the other hand, no molar mass restrictions were used when calculating the weight average molecular weight. The residuals of model fits at different peptide concentrations were observed to be in most cases $<0.05$ of the total light scattering signal.

\section{SEC-MALS}

Characterization of different self-assembly subspecies was attempted by using size-exclusion chromatography (SEG). Waters 2695 HPLC (Waters Corp., MA, USA) was connected to Biosuite 125 column $(7.8 \times 300 \mathrm{~mm}$, Waters Corp., MA, USA) and the analysis was carried out using Optilab® rEX differential refractometer and DAWN ${ }^{\circledR}$ Heleos ${ }^{\circledR}$ II MALS detector, while the data was processed using Astra 6.1 software (Wyatt Technology Corporation, CA, USA). $20 \mu \mathrm{l}$ of $50 \mathrm{mg} / \mathrm{ml}$ peptide solutions were injected in triplicate and the respective formulation buffers were used as mobile phases at $1.0 \mathrm{ml} / \mathrm{min}$ flow rate. To take into account the effect of the antimicrobial preservatives on the refractive index of the solution, the reference cell of the refractometer was flushed with the mobile phase before each measurement. 


\section{Hydrodynamic Radius Measurements}

Combination of dynamic light scattering (DLS) and rheometry was used to calculate the hydrodynamic radius of peptide self-assemblies in the absence and presence of antimicrobial preservatives. Peptide and preservative solutions in formulation buffers were filtered through $0.1 \mu \mathrm{m}$ filters (Anotop, GE Healthcare AB, Uppsala, Sweden) and mixed on 96-well plates (SensoPlate ${ }^{\text {TM }}$ Black, Greiner Bio-One Inc., $\mathrm{NC}, \mathrm{USA}$ ) in a laminar airflow cabinet to produce different mixtures with $0,1.7,3.3,5,6.7,8.3$ or $10 \mathrm{mg} / \mathrm{ml}$ of peptide and $0,2,4,6,8$ or $10 \mathrm{mg} / \mathrm{ml}$ of preservative. Diffusion coefficients $(D)$ of the light scattering units were measured using Dynapro $^{\text {TM }}$ II DLS plate reader (Wyatt Technology Corporation, CA, USA) at $25^{\circ} \mathrm{C}$. The dynamic viscosities of solutions containing $0,1.7,5$ or $10 \mathrm{mg} / \mathrm{ml}$ of peptide and 0,5 or $10 \mathrm{mg} / \mathrm{ml}$ of different preservatives (in formulation buffer) were measured in triplicate with Anton Paar Physica 301 cone-plate rheometer (Anton Paar GmbH, Graz, Austria) using $50 \mathrm{~mm}$ measurement head with $0.5^{\circ}$ angle. Measurement temperature was $25^{\circ} \mathrm{C}$, rotation speed $1000 / \mathrm{min}$, coneplate gap $0.025 \mathrm{~mm}$ and measurement time $120 \mathrm{~s}$. The apparent hydrodynamic radius $\left(r_{H}\right)$ was calculated according to the Stokes-Einstein equation describing the Brownian motion of spherical particles:

$r_{H}=\frac{k_{B} T}{6 \pi \eta D}$

where $k_{B}$ is the Boltzmann constant, $T$ is temperature and $\eta$ is the dynamic viscosity measured with cone-plate rheometer. The apparent hydrodynamic radii calculated using Eq. 3 were then used to estimate the hydrodynamic radius at infinite dilution $\left(\bar{r}_{H}\right)$ by linear extrapolation from 3.3 to $8.3 \mathrm{mg} / \mathrm{ml}$ peptide concentration range, where the correlation between the peptide concentration and apparent hydrodynamic radius was linear.

\section{Nuclear Magnetic Resonance (NMR)}

Nuclear magnetic resonance (NMR) measurements were carried out by using a $600 \mathrm{Mhz}$ Avance II+ spectrometer (Bruker BioSpin AG., Fällanden, Switzerland) equipped with a cryogenically cooled QCI probehead. Experiments were performed at $300 \mathrm{~K}$. A standard stimulated echo diffusion ordered spectroscopy (DOSY) type sequence was used with bipolar gradients for diffusion editing (21). The gradient strength of these pulses was incremented in 32 steps from 5 to $95 \%$ of the available gradient strength of the gradient amplifier in use. The diffusion time was set to $300 \mathrm{~ms}$. Solvent suppression was achieved by use of presaturation. Diffusion constants were obtained as the slope of a linear fit of the logarithm of the signal of the NMR amplitude in dependence on the square of the gradient strength (22). Examples of such plots are shown in Supplement 1 for $5 \mathrm{mg} / \mathrm{ml}$ of each antimicrobial preservative in the absence and presence of $10 \mathrm{mg} / \mathrm{ml}$ peptide.

To study the effect of peptide concentration on translational diffusion of the preservatives, the mobility of the preservatives at $5 \mathrm{mg} / \mathrm{ml}$ were measured in the presence of different peptide concentrations $(0,1.25,2.5,5$ and $10 \mathrm{mg} / \mathrm{ml})$ using DOSY measurements. If a preservative is in fast exchange between a peptide-bound and a free state, the observed diffusion constant $\left(\mathrm{D}_{\text {obs }}\right)$ is affected by the equilibrium between the population-weighted averages of the peptide-bound $\left(\mathrm{D}_{\text {pep }}\right)$ and free $\left(\mathrm{D}_{\text {free }}\right)$ preservative molecule diffusion constants, as shown by Eq. 4:

$D_{\text {obs }}=P_{p e p} * D_{\text {pep }}+P_{\text {free }} * D_{\text {free }}$

where $\mathrm{P}_{\text {pep }}$ and $\mathrm{P}_{\text {free }}$ refer to the fractions of peptide-bound and free preservative molecules, respectively. By substituting:

$P_{\text {free }}=1-P_{\text {pep }}$

the following relationship can be established:

$P_{\text {pep }}=\frac{D_{\text {obs }}-D_{\text {free }}}{D_{\text {pep }}-D_{\text {free }}}$

Since peptide-bound preservative molecules can be assumed to diffuse at the same rate as the peptide itself, Eq. 6 can be solved by measuring the diffusion coefficients of the preservative molecules in the presence $\left(D_{o b s}\right)$ and absence $\left(D_{\text {free }}\right)$ of peptide and the diffusion coefficient of the peptide $\left(D_{p e p}\right)$. The diffusion coefficients were viscosity-corrected by measuring the effect of peptide concentration on histidine mobility.

\section{Antimicrobial Efficacy Testing (AET)}

The viability of two bacterial strains, E. coli (ATCG 8739) and S. aureus (ATCG 6538), in different peptide formulations were investigated according to a modified version of Ph. Eur. 8th Ed. 5.1.3. "Efficacy of antimicrobial preservation". Sterile peptide formulations $(\mathrm{C}=0,1,5$ or $10 \mathrm{mg} / \mathrm{ml})$ containing benzyl alcohol $(\mathrm{C}=8-12 \mathrm{mg} / \mathrm{ml})$, phenol $(\mathrm{C}=4-6 \mathrm{mg} / \mathrm{ml})$ or $\mathrm{m}$-cresol $(\mathrm{C}=1.5-3 \mathrm{mg} / \mathrm{ml})$ were inoculated with microbes, and samples were drawn after 24 and $72 \mathrm{~h}$ of incubation at 20-25 ${ }^{\circ}$ C. Samples were diluted, spread on agar medium B plates (Ph. Eur. 2.6.12.) and incubated until the number of colony forming units (CFU) could be calculated. When comparing the AET results to $\mathrm{Ph}$. Eur. limit values, the reductions in CFU counts $24 \mathrm{~h}$ after the inoculation were expressed in logarithmic units, because the pharmacopoeia values are also given in this scale. Additionally, a read out after $72 \mathrm{~h}$ was used to verify the trend (i.e., decrease / no decrease in GFU) observed at the $24 \mathrm{~h}$ time point. In order to comply with $\mathrm{Ph}$. Eur. 
acceptance criteria, the $\log \mathrm{CFU}$ reduction values had to exceed either limits of level A (suggested antimicrobial efficacy) or level B (acceptable antimicrobial efficacy in case level A limit cannot be reached because of the risk of adverse reactions), which are $\log 3$ and $\log 1$ after 24 h, respectively. $72 \mathrm{~h}$ time point is not included in $\mathrm{Ph}$. Eur. 5.1.3 so no acceptance criteria could be attributed to it.

The AET results were also used to calculate how the addition of the peptide affected the antimicrobial efficacy of the formulation. In this case, the results were expressed as fraction of microbes alive 24 or $72 \mathrm{~h}$ after inoculation $(f)$ :

$f_{24 h / 72 h}=\frac{n(C F U, 24 h / 72 h)}{n(C F U, 0 h)}$

Within the linear range of the AET setup, $f$ can be plotted as a function of preservative concentration:

$c_{\text {pres }}=x f+C$

where $c_{\text {pres }}$ is the molar concentration of antimicrobial preservative, $x$ is the slope of the linear fit and $C$ is the preservative concentration required to kill or inactivate all inoculated microbes after 24 h (i.e., $f=0$ ). By plotting $f$ as a function of $c$ (pres), $\mathrm{C}$ can be calculated for a given antimicrobial preservative when including either $0 \mathrm{mg} / \mathrm{ml}, 1 \mathrm{mg} / \mathrm{ml}, 5 \mathrm{mg} / \mathrm{ml}$ or $10 \mathrm{mg} / \mathrm{ml}$ peptide in the formulation. $C$ at a given peptide concentration (denoted as $\mathrm{C}_{\mathrm{i}}$ ) was used to calculate the sequestered (i.e., not being able to diffuse freely and kill/inactivate microbes) preservative fraction $\left(f_{S}\right)$ as follows:

$f_{S}=\frac{\left(C_{i}-C_{0}\right)}{C_{i}}$

where $C_{o}$ is the preservative concentration required to kill or inactivate all inoculated microbes in the absence of peptide.

\section{RESULTS}

\section{Effect of Antimicrobial Preservatives on the Size of Peptide-Preservative Assemblies}

Figure 2 shows the hydrodynamic radii $\left(\bar{r}_{H}\right)$ of the peptide oligomers measured with DLS when using different concentrations of preservatives. An increase in preservative concentration led to an increase in $\bar{r}_{H}$ when m-cresol was used as an excipient, whereas the effects of benzyl alcohol and phenol on $\bar{r}_{H}$ were negligible. The samples containing $>8 \mathrm{mg} / \mathrm{ml} \mathrm{m}$-cresol were visibly turbid so they were excluded from the analysis.

Figure 3 shows the weight average molar mass $\left(\bar{M}_{w}\right)$ and the second virial coefficient $\left(\mathrm{A}_{2}\right)$ of the peptide oligomers as a function of antimicrobial preservative concentration, measured with CG-MALS. An increase in benzyl alcohol

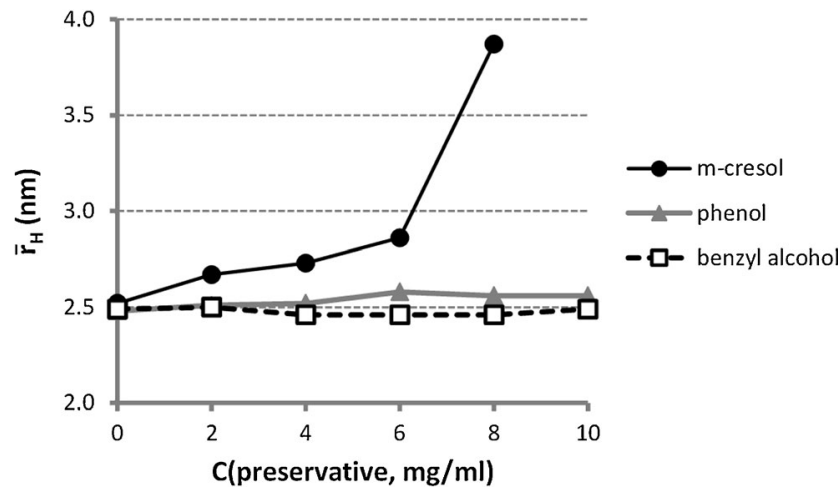

Fig. 2 The hydrodynamic radii $\left(\overline{\mathrm{r}}_{\mathrm{H}}\right)$ of peptide oligomers in formulations containing different concentrations of benzyl alcohol, phenol or m-cresol, calculated using DLS and cone-plate rheometer and extrapolating to infinite dilution in peptide concentration.

concentration had practically no impact on $\bar{M}_{w}$, and the effect of phenol was very small. However, a clear effect on the light scattering signal was observed with m-cresol, meaning that the order in which the preservatives affected the CG-MALS results was similar in which they affected the $\bar{r}_{H}$ of light scattering entities (Fig. 2). The measurable onset of $\mathrm{A}_{2}$ decrease as a function of preservative concentrations was lower for $\mathrm{m}$-cresol $(>2 \mathrm{mg} / \mathrm{ml}$ ) than for phenol or benzyl alcohol $(>4 \mathrm{mg} / \mathrm{ml}$ ), and the attractive self-interactions of peptide oligomers were dominant when $\sim 6 \mathrm{mg} / \mathrm{ml}$ of $\mathrm{m}$-cresol was added (i.e., $\mathrm{A}_{2}<0$ ). As in the DLS measurements, the samples containing $10 \mathrm{mg} / \mathrm{ml} \mathrm{m}$-cresol could not be measured, as the formulations became turbid immediately upon preservative addition.

To study the effect of buffer composition on peptidepreservative interaction, phenol $(\mathrm{C}=0-10 \mathrm{mg} / \mathrm{ml})$ was combined with the peptide $(\mathrm{C}=1.7-10 \mathrm{mg} / \mathrm{ml})$ in both $20 \mathrm{mM}$ His/His-HCl (pH 7.0) + $150 \mathrm{mM} \mathrm{NaCl}$ buffer and $20 \mathrm{mM} \mathrm{Na}$ phosphate $(\mathrm{pH} 7.0)+130 \mathrm{mM} \mathrm{NaCl}$ buffer, and the peptide oligomerization tendency was studied using CG-MALS. These $\mathrm{NaCl}$ concentrations were used because peptide $\mathrm{A}_{2}$ was almost identical in them $\left(6.0^{*} 10^{-4} \mathrm{~mol}{ }^{*} \mathrm{ml} / \mathrm{g}^{-2}\right.$ in His/His-HCl vs. $6.3 * 10^{-4} \mathrm{~mol} * \mathrm{ml} / \mathrm{g}^{-2}$ in Na-phosphate), signifying that the screening of electrostatic repulsions was equally effective in both buffers. Adding up to $10 \mathrm{mg} / \mathrm{ml}$ phenol decreased peptide $\mathrm{A}_{2}$ in both buffers (to $2.0 * 10^{-4} \mathrm{~mol} * \mathrm{ml} / \mathrm{g}^{-2}$ in His/His-HCl and to $7.6^{*} 10^{-5} \mathrm{~mol} * \mathrm{ml} / \mathrm{g}^{-2}$ in Na-phosphate) and increased 5-mer to 10-mer conversion similarly (data not shown). Although the strengthening of self-attractive peptide potential may be slightly more pronounced in Na-phosphate buffer as a function of phenol concentration as depicted by the greater decrease in $\mathrm{A}_{2}$, the data did not indicate a significant difference in peptide aggregation propensity between the buffers.

Figure 4 shows the SEC elution profiles and the apparent molar mass $\left(M_{w}\right)$ when the mobile phase contained different antimicrobial preservatives (note that no preservatives were included in the injected formulations). The preservative concentration in mobile phase was $10 \mathrm{mg} / \mathrm{ml}$ except for $\mathrm{m}$-cresol 

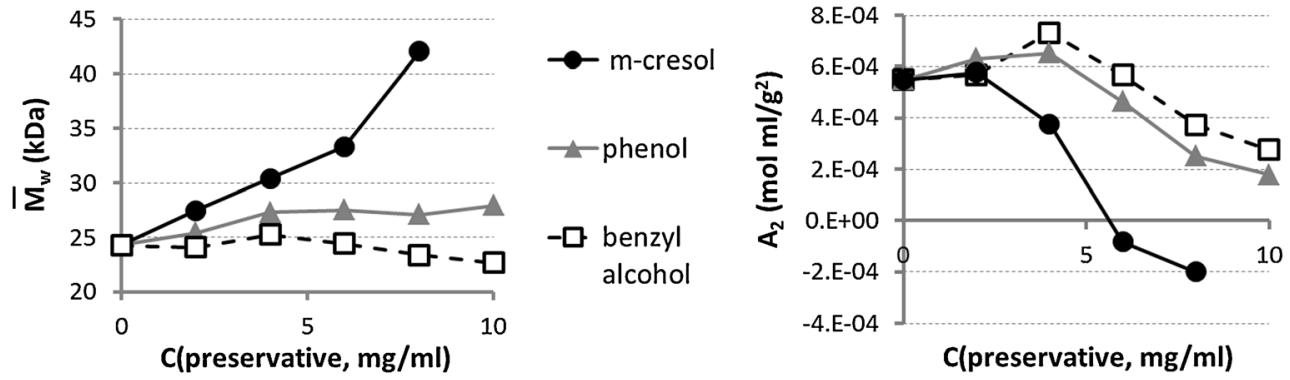

Fig. 3 Weight average molecular weight $\left(\overline{\mathrm{M}}_{\mathrm{w}}\right)$ and second virial coefficient $\left(\mathrm{A}_{2}\right)$ of the peptide oligomers as a function of antimicrobial preservative concentration, measured using GG-MALS. Each $\overline{\mathrm{M}}_{\mathrm{w}}$ and $\mathrm{A}_{2}$ value was calculated by fitting 12 measurements at different peptide concentrations (between 0.17 and $10 \mathrm{mg} / \mathrm{ml}$ ) into a reversible association model (see Materials and methods for details).

where lower concentration $(5 \mathrm{mg} / \mathrm{ml})$ was used due to peptide aggregation at $10 \mathrm{mg} / \mathrm{ml}$. The numerical results of the SEC analysis are shown in Table I. Without preservatives in the mobile phase, the peptide eluted mostly as 5-mers $(\mathrm{Mw} \sim 23 \mathrm{kDa}$, observed at the main part of the elution peak) and 4-mers $(\mathrm{Mw} \sim 18 \mathrm{kDa}$, observed at the tail of the peak), as shown in Fig. 4(a). Including preservatives in the mobile phase (Figs. 4(bd)) did not cause any high molecular weight (aggregate) peaks to appear. Very similar molar masses were observed at the elution peaks of the SEC measurements as were seen in the CG-MALS experiments, when

a

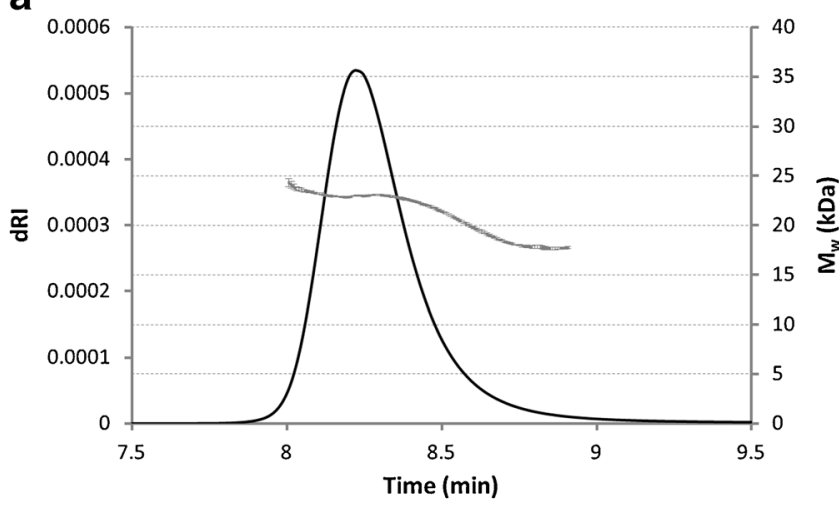

c

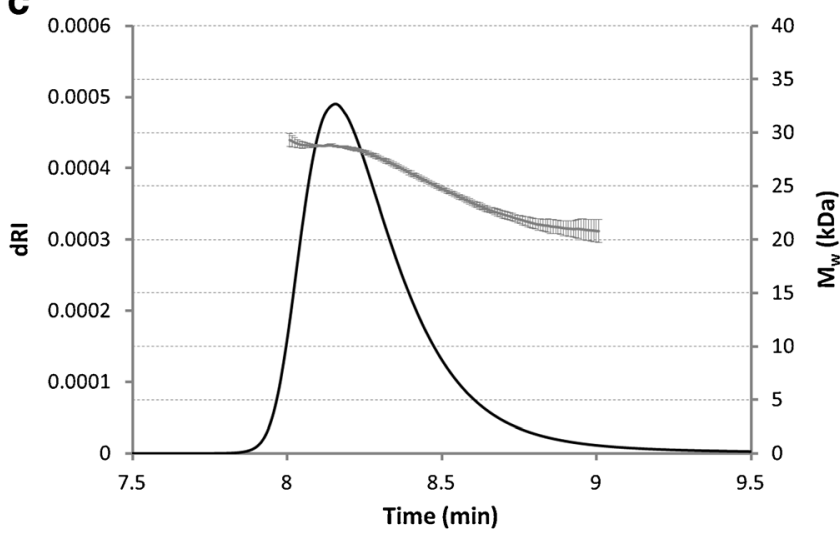

comparing the peptide $\mathrm{M}_{\mathrm{w}}$ (Table I) to the $\bar{M}_{w}$ results (Fig. 3) at respective preservative concentrations.

Inclusion of $10 \mathrm{mg} / \mathrm{ml}$ phenol and $5 \mathrm{mg} / \mathrm{ml} \mathrm{m}$-cresol affected the elution profile of the peptide by causing the peptide to elute earlier, increasing the half-width of the peak and decreasing the peak height (Table I). This could have been caused either by an increase in average peptide oligomer size or stronger column interactions when using a mobile phase containing phenol or m-cresol. All preservatives increased peak area slightly, possibly due to a formation of a preservative-rich layer around the peptide oligomers which changed the refractive index of the solution at elution peak.

b

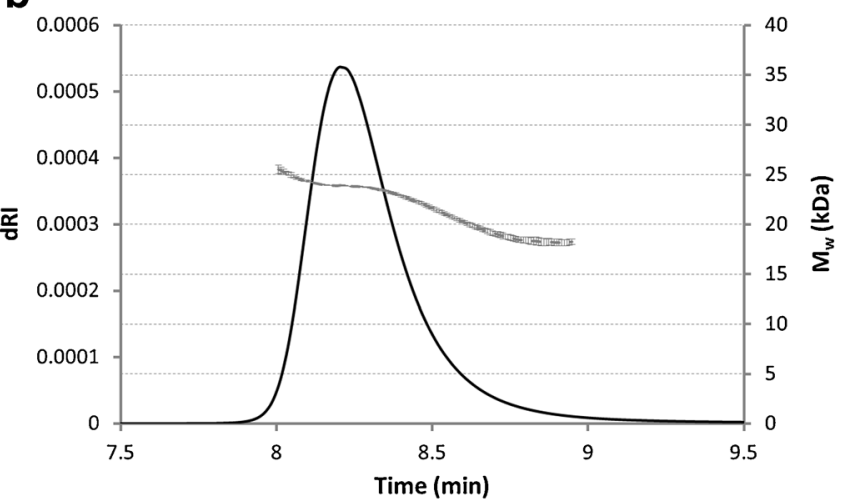

d

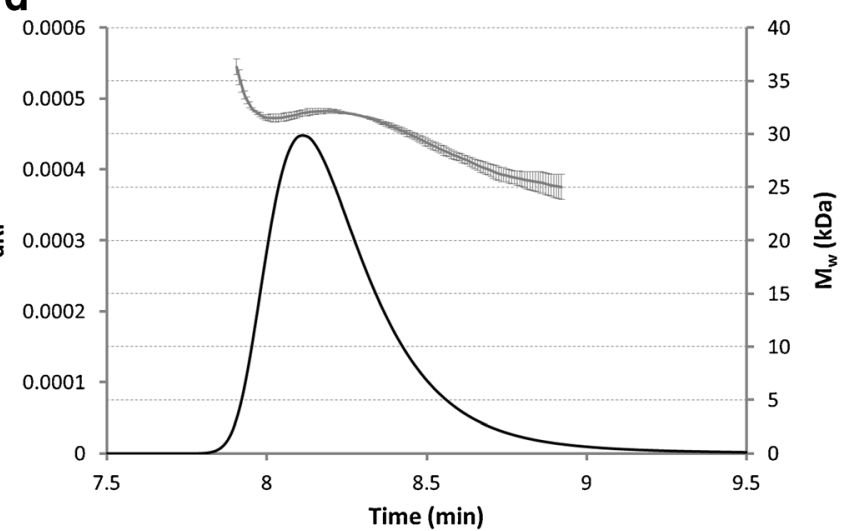

Fig. 4 Average $(n=3)$ SEC elution profiles of the peptide $\left(M_{w} \sim 4.5 \mathrm{kDa}\right)$ when using no preservatives in the mobile phase $(\mathbf{a})$, or when including $10 \mathrm{mg} / \mathrm{ml}$ benzyl alcohol (b), $10 \mathrm{mg} / \mathrm{ml}$ phenol (c) or $5 \mathrm{mg} / \mathrm{ml} \mathrm{m}$-cresol (d). The solid lines show the signal from dRI detector, whereas the dashed lines represent the molar mass $\left(M_{w}\right)$ calculated from $\mathrm{dRI}$ and MALS detectors. 
Table I The Numerical Results of SEC Analysis, Including the Onset of Elution [T(onset)], Peak Elution Time [T(max)], Peak Half-Width [W(I/2)], Normalized Peak Height $[\mathrm{dRI}(\max )]$, Normalized Peak Area and Apparent Molar Mass $\left(M_{w}\right)$ at peak $(n=3)$

\begin{tabular}{lllllll}
\hline Preservative in mobile phase & $T($ onset, $\min )$ & $T(\max , \min )$ & $\mathrm{W}(\mathrm{I} / 2, \mathrm{~min})$ & $\mathrm{dRI}(\max )$ & peak area & $M_{w}$ at peak $(\mathrm{kDa})$ \\
\hline none & 7.88 & 8.21 & 0.30 & $100 \%$ & $100 \%$ & 22.9 \\
$10 \mathrm{mg} / \mathrm{ml}$ benzyl alcohol & 7.90 & 8.20 & 0.30 & $100 \%$ & $102 \%$ & 23.8 \\
$10 \mathrm{mg} / \mathrm{ml}$ phenol & 7.86 & 8.15 & 0.35 & $91.7 \%$ & $104 \%$ & 28.7 \\
$5 \mathrm{mg} / \mathrm{ml}$ m-cresol & 7.83 & 8.11 & 0.36 & $83.7 \%$ & $101 \%$ & 31.9 \\
\hline
\end{tabular}

\section{Antimicrobial Efficacy of Peptide/Preservative Formulations}

The antimicrobial efficacy testing (AET) was carried out by spiking $E$. coli and $S$. aureus into the sterile formulations and analyzing the remaining fractions of live microbes after $24 \mathrm{~h}$ and $72 \mathrm{~h}$ incubation period. These time points were used because preliminary tests showed that achieving sufficiently low microbial viabilities was most difficult when the incubation times were relatively short. Low microbe viability after incubation therefore depicts better antimicrobial efficacy for a given formulation. E. coli and $S$. aureus were selected because, as confirmed in preliminary testing, these strains were more resistant to the antimicrobial preservatives than the other strains which are accepted in the Ph. Eur. AET scheme (i.e., P. aeruginosa, C. albicans and A. braziliensis, data not shown). Therefore, using $E$. coli and $S$. aureus in the AET allowed the study to focus on the strains which were most difficult to kill or inactivate. Additionally, $S$. aureus is a gram positive and $E$. coli a gram negative microbial strain, and it was important to check whether their different cell wall structures affected the outcome of the AET results when using different antimicrobial preservatives.

The results of the antimicrobial efficacy test are shown in Table II. As expected, higher preservative concentrations generally resulted in better antimicrobial efficacy (i.e., higher log CFU reduction values). At the same time, the antimicrobial efficacy decreased in most cases when increasing the peptide concentration. This decrease was often significant enough to lower a sample from one $\mathrm{Ph}$. Eur. acceptance criterion class to another (e.g., from level A to level B, or from level B to noncompliance). While at certain preservative concentrations no changes in microbial viability were observed between low and high peptide concentrations (e.g., $8 \mathrm{mg} / \mathrm{ml}$ benzyl alcohol), the antimicrobial efficacy of such formulations was so low that it had only a minor effect on microbial viability. Therefore it was difficult to estimate whether the addition of peptide had a negative effect on their (already low) antimicrobial efficacy. The preservatives were not always equally effective against both bacterial strains, and especially benzyl alcohol seemed less effective against $S$. aureus than $E$. coli in this study. The log CFU reductions after $72 \mathrm{~h}$ incubation were always higher than or equal to the ones obtained $24 \mathrm{~h}$ after inoculation.
To study whether the decrease in antimicrobial efficacy as a function of peptide concentration could be caused by the microbes using the peptide as nutrient for faster replication, selected $E$. coli AET tests were repeated for formulations containing $5 \mathrm{mg} / \mathrm{ml}$ phenol and $1-10 \mathrm{mg} / \mathrm{ml}$ peptide by also adding $250 \mathrm{mM}$ trehalose in the buffer. Since $E$. coli can utilize trehalose as its sole carbon and energy source (23), such formulations contained excess nutrients and thus minimized the need for the microbe to use the peptide as an energy source. $24 \mathrm{~h}$ after inoculating the trehalose-containing formulations with $E$. coli, the $\log$ CFU reduction values were 1.2, 0.7 and 0.5 for 1,6 and $10 \mathrm{mg} / \mathrm{ml}$ peptide concentrations, respectively. These values were lower than those of $5 \mathrm{mg} / \mathrm{ml}$ phenol formulations without trehalose (Table II), suggesting microbe multiplication was faster in such nutrient-rich (i.e., trehalosecontaining) formulations. Still, an increase in peptide concentration was shown to decrease the antimicrobial efficacy of the formulation even in the presence of trehalose.

\section{Comparison Between Peptide-Bound and Sequestered Preservative Fractions}

The results of Table II suggest that antimicrobial efficacy of preservatives was lowered by the peptide. This might mean that in such formulations the preservatives exist either as freely diffusing molecules and thus being able to affect microbial viability, or as peptide-bound molecules which are sequestered to the vicinity of peptide oligomers and thus unable to affect microbial viability. To test this hypothesis, the peptidebound preservative fractions $\left(\mathrm{P}_{\mathrm{pep}}\right.$, calculated from the NMR results using Eqs. 4-6) and sequestered preservative fractions $\left(f_{\mathrm{s}}\right.$, calculated from AET results using Eqs. 7-9) were plotted in Fig. 5. This was done to analyze whether the percentage of peptide-bound preservative molecules correlated with the extent of lost antimicrobial efficacy. It should be noted that only the linear regions of $f$ vs. $c$ (pres) curves (Eq. 8) were used in calculating the sequestered preservative fractions (Eq. 9), because at low preservative concentrations there was no observable bacteriocidic effect. On the other hand, when the preservative concentration exceeded $C$ (Eq. 8), all microbes were eliminated and increasing the concentration further had no additional effect. Such preservative concentrations were therefore also excluded. 
Table II Antimicrobial Efficacy Testing (AET) Results for E. coli and S. aureus in the Presence of Different Peptide $\left(c_{\text {pep }}\right)$ and Preservative ( $\left.c_{\text {pres }}\right)$ Concentrations. The Results are Expressed as Logarithmic Colony Forming Unit (log CFU) Reductions and Fractions of Live Microbes ( $f$ ) After $24 \mathrm{~h}$ or $72 \mathrm{~h}$ Incubation. The log CFU Columns for $24 \mathrm{~h}$ Incubation Time Points Also Include a Marking Whether the Formulations Fulfilled Ph. Eur. level A (Marked with "A") or level B (Marked with "B") Acceptance Criteria, or Whether they Failed to Comply with Both (Marked with "F"). The $72 \mathrm{~h}$ Incubation Point is not Included in the Ph. Eur. criteria so no Acceptance Criteria Could be Attributed for this Time Point

Benzyl alcohol

E. coli

c pres

$8 \mathrm{mg} / \mathrm{ml}$

(1)

$10 \mathrm{mg} / \mathrm{ml}$

$$
C_{\text {pep }}
$$

$0 \mathrm{mg} / \mathrm{ml}$

I $\mathrm{mg} / \mathrm{ml}$

$5 \mathrm{mg} / \mathrm{ml}$

$10 \mathrm{mg} / \mathrm{ml}$

$0 \mathrm{mg} / \mathrm{ml}$

I $\mathrm{mg} / \mathrm{ml}$

$5 \mathrm{mg} / \mathrm{ml}$

$10 \mathrm{mg} / \mathrm{ml}$

I $\mathrm{mg} / \mathrm{ml}$

$0 \mathrm{mg} / \mathrm{ml}$

I $\mathrm{mg} / \mathrm{ml}$

$5 \mathrm{mg} / \mathrm{ml}$

$10 \mathrm{mg} / \mathrm{ml}$

$12 \mathrm{mg} / \mathrm{ml}$

$$
0 \mathrm{mg} / \mathrm{ml}
$$

$1 \mathrm{mg} / \mathrm{ml}$

$5 \mathrm{mg} / \mathrm{ml}$

$10 \mathrm{mg} / \mathrm{ml}$

Phenol

E. coli

Cpres

$4 \mathrm{mg} / \mathrm{ml}$

$C_{\text {pep }}$

$0 \mathrm{mg} / \mathrm{ml}$

I $\mathrm{mg} / \mathrm{ml}$

$5 \mathrm{mg} / \mathrm{ml}$

$10 \mathrm{mg} / \mathrm{ml}$

log CFU reduction

$24 \mathrm{~h} \quad 72 \mathrm{~h}$

$0.3(\mathrm{~F})$

$0.3(\mathrm{~F})$

$0.3(\mathrm{~F})$

$0.3(\mathrm{~F})$

$0.8(\mathrm{~F})$

$0.6(\mathrm{~F})$

$0.4(\mathrm{~F})$

$0.3(\mathrm{~F})$

$3.8(\mathrm{~A})$

1.8 (B)

$0.8(\mathrm{~F})$

$0.5(\mathrm{~F})$

$3.7(\mathrm{~A})$

$3.7(\mathrm{~A})$

$3.7(\mathrm{~A})$

2.4 (B)

log CFU reduction

\section{$24 \mathrm{~h}$}

1.6 (B)

$0.4(\mathrm{~F})$

$0.3(\mathrm{~F})$

$0.2(\mathrm{~F})$

$5 \mathrm{mg} / \mathrm{ml}$

$0 \mathrm{mg} / \mathrm{ml}$

$3.7(\mathrm{~A})$

I $\mathrm{mg} / \mathrm{ml}$

$5 \mathrm{mg} / \mathrm{ml}$

$2.6(\mathrm{~B})$

$10 \mathrm{mg} / \mathrm{ml}$

$1.9(\mathrm{~B})$

$1.0(\mathrm{~B})$

$6 \mathrm{mg} / \mathrm{ml}$

$$
0 \mathrm{mg} / \mathrm{ml}
$$

$3.7(\mathrm{~A})$

| $\mathrm{mg} / \mathrm{ml}$

$3.7(\mathrm{~A})$

$5 \mathrm{mg} / \mathrm{ml}$

3.7 (A)

$10 \mathrm{mg} / \mathrm{ml}$

$3.7(\mathrm{~A})$

m-cresol

E. coli

Cpres

$1.5 \mathrm{mg} / \mathrm{ml}$

$C_{\text {pep }}$

$0 \mathrm{mg} / \mathrm{ml}$

log CFU reduction

$24 \mathrm{~h}$

$1.6(\mathrm{~B})$

I $\mathrm{mg} / \mathrm{ml}$

$0.1(\mathrm{~F})$

$5 \mathrm{mg} / \mathrm{ml}$

$0.2(\mathrm{~F})$

$10 \mathrm{mg} / \mathrm{ml}$

$0.2(\mathrm{~F})$

$3.8(\mathrm{~A})$

$0.9(\mathrm{~F})$

$1 \mathrm{mg} / \mathrm{ml}$

$0.2(\mathrm{~F})$

$5 \mathrm{mg} / \mathrm{ml}$

$0.2(\mathrm{~F})$

$2.5 \mathrm{mg} / \mathrm{ml}$

$0 \mathrm{mg} / \mathrm{ml}$

$3.8(A)$

$$
72 \mathrm{~h}
$$

3.7

$$
3.4
$$

$$
2.3
$$

1.5

3.7

3.7

$72 \mathrm{~h}$

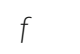

$24 \mathrm{~h}$

0.50

0.50

0.50

0.50

0.16

0.25

0.40

0.50

0.00

0.02

0.16

0.32

0.00

0.00

0.00

0.00

\section{$f$}

$24 \mathrm{~h} \quad 72 \mathrm{~h}$

$0.03 \quad 0.00$

$0.40 \quad 0.00$

$0.50 \quad 0.01$

$0.63 \quad 0.03$

$0.00 \quad 0.00$

$0.00 \quad 0.00$

$0.01 \quad 0.00$

$0.10 \quad 0.00$

$0.00 \quad 0.00$

$0.00 \quad 0.00$

$0.00 \quad 0.00$

$0.00 \quad 0.00$

S. aureus
Cpres
$8 \mathrm{mg} / \mathrm{ml}$
$10 \mathrm{mg} / \mathrm{ml}$
$11 \mathrm{mg} / \mathrm{ml}$
$12 \mathrm{mg} / \mathrm{ml}$

S. aureus

cpres

$4 \mathrm{mg} / \mathrm{ml}$

.

$5 \mathrm{mg} / \mathrm{ml}$

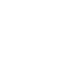

$6 \mathrm{mg} / \mathrm{ml}$

$$
3.7
$$$$
3.7
$$

3.7

\section{f}

$24 \mathrm{~h}$

0.03

0.79

0.63

0.63

$\begin{array}{ll}0.63-0.16 \\ 0.00 & 0.00\end{array}$

$0.00 \quad 0.00$

$0.13 \quad 0.00$

$0.63 \quad 0.06$

$0.63 \quad 0.16$

\begin{tabular}{|c|c|c|c|c|}
\hline \multirow[b]{2}{*}{$C_{\text {pep }}$} & \multicolumn{2}{|c|}{$\log$ CFU reduction } & \multicolumn{2}{|l|}{$f$} \\
\hline & $24 \mathrm{~h}$ & $72 \mathrm{~h}$ & $24 \mathrm{~h}$ & $72 \mathrm{~h}$ \\
\hline $0 \mathrm{mg} / \mathrm{ml}$ & $0.0(\mathrm{~F})$ & 1.3 & 1.00 & 0.05 \\
\hline I mg/ml & $0.0(F)$ & 0.6 & 1.00 & 0.25 \\
\hline $5 \mathrm{mg} / \mathrm{ml}$ & $0.0(F)$ & 1.2 & 1.00 & 0.06 \\
\hline $10 \mathrm{mg} / \mathrm{ml}$ & $0.1(F)$ & 1.8 & 0.79 & 0.02 \\
\hline 0 mg/ml & $0.1(F)$ & 3.3 & 0.79 & 0.00 \\
\hline I mg/ml & $0.0(F)$ & 2.0 & 1.00 & 0.01 \\
\hline $5 \mathrm{mg} / \mathrm{ml}$ & $0.3(F)$ & 2.4 & 0.50 & 0.00 \\
\hline $10 \mathrm{mg} / \mathrm{ml}$ & $0.2(F)$ & 1.7 & 0.63 & 0.02 \\
\hline 0 mg/ml & $1.7(\mathrm{~B})$ & 3.8 & 0.02 & 0.00 \\
\hline I mg/ml & $0.8(\mathrm{~F})$ & 3.8 & 0.16 & 0.00 \\
\hline $5 \mathrm{mg} / \mathrm{ml}$ & $0.6(F)$ & 2.2 & 0.25 & 0.01 \\
\hline $10 \mathrm{mg} / \mathrm{ml}$ & $0.6(F)$ & 1.7 & 0.25 & 0.02 \\
\hline $0 \mathrm{mg} / \mathrm{ml}$ & $0.8(\mathrm{~F})$ & 3.3 & 0.16 & 0.00 \\
\hline I mg/ml & $0.1(F)$ & 2.2 & 0.79 & 0.01 \\
\hline $5 \mathrm{mg} / \mathrm{ml}$ & $0.9(F)$ & 3.4 & 0.13 & 0.00 \\
\hline $10 \mathrm{mg} / \mathrm{ml}$ & $0.7(F)$ & 3.1 & 0.20 & 0.00 \\
\hline
\end{tabular}

$0.00 \quad 0.00$

$0.00 \quad 0.00$

S. aureus

Cpres

I. $5 \mathrm{mg} / \mathrm{ml}$

$2 \mathrm{mg} / \mathrm{ml}$ $\log$ CFU reduction

$$
c_{\text {pep }}
$$

$0 \mathrm{mg} / \mathrm{ml}$

$24 \mathrm{~h}$

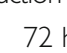

I $\mathrm{mg} / \mathrm{ml}$

$0.3(\mathrm{~F})$

3.3

$5 \mathrm{mg} / \mathrm{ml}$

$0.0(\mathrm{~F})$

$10 \mathrm{mg} / \mathrm{ml}$

$0.0(\mathrm{~F})$

$0 \mathrm{mg} / \mathrm{ml}$

I $\mathrm{mg} / \mathrm{ml}$

$0.2(\mathrm{~F})$

$5 \mathrm{mg} / \mathrm{ml}$

$$
\text { I.I (B) }
$$

$10 \mathrm{mg} / \mathrm{ml}$

$$
0.4(\mathrm{~F})
$$

$0 \mathrm{mg} / \mathrm{ml}$

$$
0.8(\mathrm{~F})
$$

I $\mathrm{mg} / \mathrm{ml}$

$3.3(\mathrm{~A})$

$5 \mathrm{mg} / \mathrm{ml}$

$2.6(\mathrm{~B})$

$10 \mathrm{mg} / \mathrm{ml}$

$3.4(\mathrm{~A})$

$2.5(\mathrm{~B})$

$\log$ CFU reduction

$c_{\text {pep }}$

$0 \mathrm{mg} / \mathrm{ml}$

$24 \mathrm{~h}$

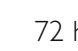

$0.5(\mathrm{~F})$

I $\mathrm{mg} / \mathrm{ml}$

$0.2(\mathrm{~F})$

$5 \mathrm{mg} / \mathrm{ml}$

$0.3(\mathrm{~F})$

$10 \mathrm{mg} / \mathrm{ml}$

$0.2(\mathrm{~F})$

$0 \mathrm{mg} / \mathrm{ml}$

1.6 (B)

I $\mathrm{mg} / \mathrm{ml}$

$0.2(F)$

$5 \mathrm{mg} / \mathrm{ml}$

$0.2(F)$

$10 \mathrm{mg} / \mathrm{ml}$

$0.4(F)$

$2.5 \mathrm{mg} / \mathrm{ml}$

$0 \mathrm{mg} / \mathrm{ml}$

3.5 (A)

I.I (B)

I $\mathrm{mg} / \mathrm{ml}$ $f$

$24 \mathrm{~h} \quad 72 \mathrm{~h}$

$0.50 \quad 0.00$

$1.00 \quad 0.02$

$1.00 \quad 0.06$

$0.63 \quad 0.01$

$0.00 \quad 0.00$

$0.08 \quad 0.00$

$0.40 \quad 0.00$

$0.16 \quad 0.00$

$0.00 \quad 0.00$

$0.00 \quad 0.00$

$0.00 \quad 0.00$

$0.00 \quad 0.00$

$f$

$24 \mathrm{~h} \quad 72 \mathrm{~h}$

$0.32 \quad 0.08$

$\begin{array}{ll}0.63 & 0.13\end{array}$

$0.50 \quad 0.25$

$0.63 \quad 0.25$

$0.03 \quad 0.00$

$0.63 \quad 0.00$

$0.63 \quad 0.13$

$0.40 \quad 0.13$

$0.00 \quad 0.00$

$0.08 \quad 0.00$
1.1 (B) 
Table II (continued)

\begin{tabular}{|c|c|c|c|c|c|c|c|c|c|c|c|}
\hline & $5 \mathrm{mg} / \mathrm{ml}$ & $3.8(\mathrm{~A})$ & 3.8 & 0.00 & 0.00 & & $5 \mathrm{mg} / \mathrm{ml}$ & $0.6(F)$ & 3.8 & 0.25 & 0.00 \\
\hline & $10 \mathrm{mg} / \mathrm{ml}$ & $1.2(\mathrm{~B})$ & 3.8 & 0.06 & 0.00 & & $10 \mathrm{mg} / \mathrm{ml}$ & $0.6(F)$ & 2.2 & 0.25 & 0.01 \\
\hline \multirow[t]{4}{*}{$3 \mathrm{mg} / \mathrm{ml}$} & $0 \mathrm{mg} / \mathrm{ml}$ & $3.8(\mathrm{~A})$ & 3.8 & 0.00 & 0.00 & $3 \mathrm{mg} / \mathrm{ml}$ & $0 \mathrm{mg} / \mathrm{ml}$ & $3.8(A)$ & 3.8 & 0.00 & 0.00 \\
\hline & I mg/ml & $3.8(\mathrm{~A})$ & 3.8 & 0.00 & 0.00 & & I mg/ml & $3.8(A)$ & 3.8 & 0.00 & 0.00 \\
\hline & $5 \mathrm{mg} / \mathrm{ml}$ & $3.8(\mathrm{~A})$ & 3.8 & 0.00 & 0.00 & & $5 \mathrm{mg} / \mathrm{ml}$ & $2.2(\mathrm{~B})$ & 3.8 & 0.01 & 0.00 \\
\hline & 10 mg/ml & $3.8(A)$ & 3.8 & 0.00 & 0.00 & & 10 mg/ml & I.I (B) & 3.8 & 0.08 & 0.00 \\
\hline
\end{tabular}

A reasonably good correlation was observed between the NMR and AET data (Fig. 5), even though the peptide-bound fractions $\left(\mathrm{P}_{\text {pep }}\right)$ measured by NMR were sometimes higher than the sequestered preservative fractions $\left(f_{S}\right)$ measured by AET using $E$. coli and $S$. aureus. More specifically, the largest differences between $\mathrm{P}_{\text {pep }}$ and $\mathrm{f}_{\mathrm{S}}$ values were observed for phenol and $\mathrm{m}$ cresol at $10 \mathrm{mg} / \mathrm{ml}$ peptide concentrations. It was unclear whether this was caused by the difficulties in $f_{S}$ calculation in such samples or because some other phenomenon besides peptide binding affected the antimicrobial efficacy of phenol and mcresol at high peptide concentrations. Nonetheless, it was evident that lowest bound/sequestered fractions were observed with benzyl alcohol, followed by phenol, while m-cresol displayed highest fractions for a given concentration of peptide.

\section{DISCUSSION}

The purpose of this study was to explore the effects of three antimicrobial preservatives, benzyl alcohol, m-cresol and phenol, on the oligomerization of a model peptide containing a covalently-added palmitoyl chain. Furthermore, the antimicrobial efficacy (i.e., the rate of microbial inactivation after inoculation with bacteria) of different preservative- and peptide-containing formulations were compared in order to assess whether peptide-preservative interactions can have an effect on the antimicrobial efficacy of the preservative and thus on bacterial viability.

The three preservatives studied here are commonly used in multidose protein and peptide formulations (4) and their molecular structures resemble each other closely (see Fig. 1), although it should be noted that phenol and m-cresol are classified as phenols and benzyl alcohol as aromatic alcohol. In our study, we observed that the presence of certain preservatives increases the size of the light scattering entities (Figs. 2, 3 and 4). Benzyl alcohol had practically no effect on dynamic (DLS) and static (CG-MALS and SEC-MALS) light scattering results, and only a very small increase in molar mass (both $\bar{M}_{w}$ and $M_{w}$ ) was observed when including phenol in the peptide solution. On the other hand, a significant size increase in all light scattering studies was observed when m-cresol was used, ultimately leading to visible aggregate formation at $\mathrm{C}(\mathrm{m}$ -
Fig. 5 Comparison between the fractions of peptide-bound preservative $\left[\mathrm{P}_{\text {pep }}\right.$,

$C($ preservative $)=5 \mathrm{mg} / \mathrm{ml}]$ calculated from NMR results against the sequestered preservative fractions $\left(\mathrm{f}_{\mathrm{S}}\right)$ calculated from AET results when incubating either $\mathrm{E}$. coli or S. aureus with benzyl alcohol (a), phenol (b) and m-cresol (c). a

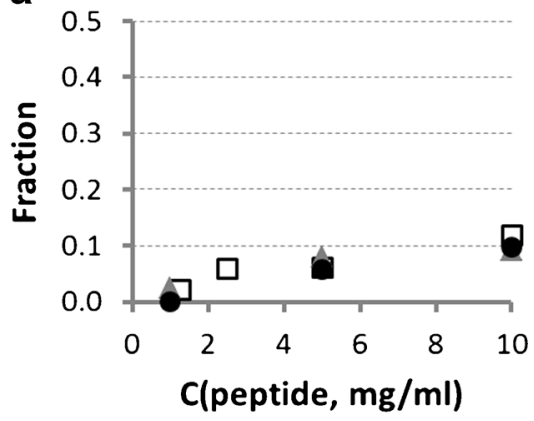

C

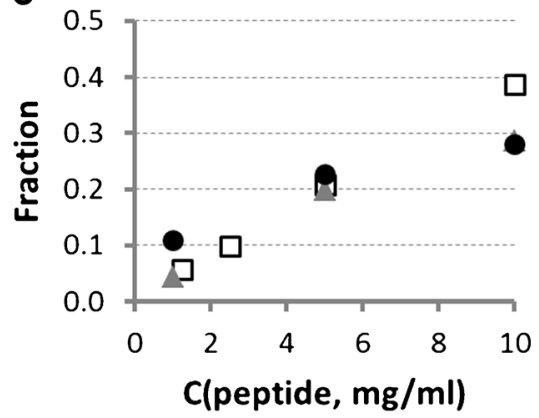

b

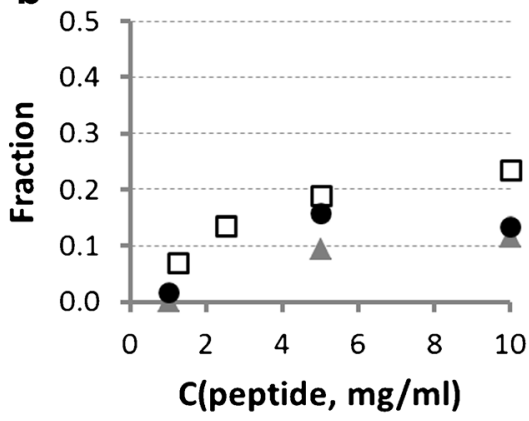

$\square \mathrm{P}_{\text {pep }}$ (NMR)

$\Delta \mathrm{f}_{\mathrm{s}}($ E. coli $)$

- $f_{s}$ (S. aureus) 
cresol) $>8 \mathrm{mg} / \mathrm{ml}$. No aggregates were observed in SEC analyses with $10 \mathrm{mg} / \mathrm{ml}$ benzyl alcohol and phenol, or with $5 \mathrm{mg} / \mathrm{ml} \mathrm{m}$-cresol in the mobile phase (Fig. 4). When measured with GG-MALS, the attractive forces between peptide oligomers became stronger at increasing preservative concentrations, as shown in Fig. 3. Still, all the effects observed with light scattering techniques, including changes in $\bar{r}_{H}, \mathrm{M}_{\mathrm{w}}, \bar{M}_{w}$ and $\mathrm{A}_{2}$, were relatively small when benzyl alcohol and phenol were used at $0-10 \mathrm{mg} / \mathrm{ml}$ concentrations, and only m-cresol was shown to have an effect which could be linked with clear peptide oligomerization state changes at such concentrations. In order to corroborate the light scattering results, AUC was evaluated as an orthogonal sizing method, but a meaningful interpretation of the peptide signals was not possible due to the strong UV absorption of the preservatives when they were used at similar concentrations as in the DLS, CG-MALS and SEC-MALS experiments (data not shown). Similarly, circular dichroism (CD) was evaluated to study the three-dimensional structure of the peptide in the presence of preservatives, but it could not be effectively employed because the preservatives absorb strongly at far-UV range, and at the near-UV range the peptide CD signal was relatively weak (data not shown).

For the purpose of evaluating the antimicrobial efficacy of peptide/preservative formulations, the Ph. Eur. antimicrobial efficacy test (AET) was used. As expected, higher preservative concentrations generally resulted in better antimicrobial efficacies, but the efficacy was also shown to decrease with increasing peptide concentrations (Table II). Most significant changes in antimicrobial efficacy as a function of peptide concentration were seen with m-cresol, followed by phenol, while least changes were seen when benzyl alcohol was used. This is the same ranking order with which these preservatives have been shown to induce the aggregation of several different proteins $(7,9,10)$. However, our study is the first one to propose that the interaction may also lead to the reduction of their antimicrobial efficacy with increasing concentrations of peptide in the same ranking order. This effect was significant, because in many cases it led to non-compliance in the $\mathrm{Ph}$. Eur acceptance criteria (Table II). The decrease in antimicrobial efficacy as a function of peptide concentration was also observed in formulations containing trehalose as additional energy source for $E$. coli. This result indicates that the reduced antibacterial efficacy cannot be explained by the bacteria using the peptide as a carbon and energy source for faster growth. The decrease in antimicrobial efficacy as a function of peptide concentration was generally more clearly seen when using $E$. coli as opposed to $S$. aureus, perhaps because the former has been shown to be more susceptible to the antimicrobial effect of aromatic alcohols (Sic.) than the latter (24). Also, pH 7 is not optimal for the antimicrobial efficacy of benzyl alcohol, whereas this is not the case for phenol or mcresol (4). These may have been possible causes for the relatively low $\log \mathrm{CFU}$ reduction values for $S$. aureus when using benzyl alcohol (the only aromatic alcohol in this study) as preservative (Table II). It should also be noted that when the inoculated formulations were incubated for $72 \mathrm{~h}$, the $\log \mathrm{CFU}$ reduction was always higher than or equal to the ones obtained $24 \mathrm{~h}$ after inoculation. This suggests that the number of live microbes continues to decrease after $24 \mathrm{~h}$, making it possible to fulfil the acceptance criteria of the subsequent Ph. Eur. AET time points (7, 14 and 28 days).

Using Eqs. 7-9, the effect of increasing peptide concentration on the sequestered preservative fractions could be compared with the peptide-bound fractions calculated from the NMR data using Eqs. 4-6 (Fig. 5). These datasets show a reasonable correlation, and at $10 \mathrm{mg} / \mathrm{ml}$ peptide concentration they also revealed the same ranking order at which the preservatives affected the light scattering signal of peptide assemblies (benzyl alcohol $<$ phenol $<$ m-cresol). This suggests that a given fractions of preservative molecules interact with peptide oligomers, thus becoming sequestered and not being able to diffuse freely in the aqueous solution. This can lead in some cases to an increase in peptide oligomerization state as well as to a decrease in the antimicrobial efficacy of the formulation. The ranking order of preservative molecules' interaction intensities with the peptides (benzyl alcohol $<$ phenol $<$ m-cresol) correlated with their logarithmic octanol/water partition coefficients $\left(\log \mathrm{P}_{\mathrm{O} / \mathrm{W}}\right)$, which are 1.1, 1.5 and 2.0, respectively (25). Also, it has been previously suggested that aromatic alcohols (Sic!) with higher heptane/water partition coefficients tend to display lower minimal concentrations at which they inhibit bacterial proliferation (24). If this trend can also be extended to other classes of molecules, such as phenols, it may mean that more lipophilic preservatives can generally be more effective as antimicrobial agents, at least as long as they remain water-soluble. Indeed, the concentrations $(\mathrm{m} / \mathrm{V})$ needed to reach $\mathrm{Ph}$. Eur. antimicrobial efficacy limits for the three preservatives used here decreased in the same order as their $\log \mathrm{P}_{\mathrm{O} / \mathrm{W}}$ values increased (Table II). The flipside of this attribute may be that as their antimicrobial efficacy increases, so does their tendency to interact with peptides and proteins. However, it is unlikely that the intensity of the interaction can be predicted based purely on the hydrophobicity of the preservative molecules, and as mentioned in the Introduction, other intermolecular forces besides hydrophobicity have been suggested to contribute to the interaction (5, 11-13). For example, the propensities of the preservative molecules to form $\pi$-interactions and hydrogen bonds would also be different, especially between phenols (i.e., phenol and m-cresol) and aromatic alcohols (i.e., benzyl alcohol).

Furthermore, the peptide structure and assembly might play a role in determining the overall level of interaction. For example, assembling peptide monomers into higher oligomeric structures containing a hydrophobic core might affect their interaction propensity with preservatives. Literature suggests that formulation components containing hydrophobic 
cores, such as surfactant micelles, can have a negative effect on the antimicrobial efficacy of preservatives, and the antimicrobial efficacy of methylparahydroxybenzoate has been shown to be weaker in the presence of polysorbate 80 (26). This effect has been attributed to preservative - surfactant interactions, which have been proposed to take place both at the polyoxyethylene - hydrocarbon junction and at the nonpolar core of surfactant micelles (27). A comparable interaction mechanism could account for the decrease in antimicrobial efficacy of preservatives in the presence of palmitoylated peptides which, like surfactants, are also relatively amphiphilic molecules. Since acylation has been shown to affect the strength at which peptides bind to hydrophobic surfaces (28), it is likely that it could also affect peptide/preservative interactions. The primary sequence of the peptide is another factor which might play a role in the determination of the overall interaction intensity. It has been suggested that polyphenols interact preferentially with amino acid residues with heterocyclic or aromatic side groups, such as proline and phenylalanine, although the conformation of the peptide dictates whether the reactive moieties of these residues are exposed or buried $(29,30)$. Since 10 amino acid residues out of 40 in the peptide primary sequence were either heterocyclic or aromatic (in this case proline, phenylalanine, tyrosine and tryptophan), and since its C-terminus was acylated with palmitoyl, the peptide in question may be especially prone to interact with preservatives. Nonetheless, the abundance of polypeptide-structured macromolecules (e.g., 5, 7-9) which have been shown to interact with different antimicrobial preservatives suggests that the binding can be unspecific by nature and should be taken into account regardless of the primary structure of the polypeptide in question.

\section{CONCLUSIONS}

Antimicrobial preservatives were shown to interact with an acylated peptide with an intensity which increases in the order benzyl alcohol $<$ phenol $<$ m-cresol. The interaction affected the size of the peptide oligomers as well as the mobility of the preservatives, especially in the case of m-cresol. Furthermore, the antimicrobial efficacy of all preservatives was weakened by the presence of the peptide, and this effect could be correlated with the molecular mobility of the preservatives, suggesting that the reduced mobility of a peptide bound state of the preservatives makes them less effective against microbes. Although the interaction intensity correlates with the overall lipophilicity of antimicrobial preservatives, its molecular mechanism has not been fully elucidated, evoking the need for further studies in this field. Still, taking into account this study and the literature already available on proteinpreservative interactions, the intensity with which benzyl alcohol (aromatic alcohol) interacts with polypeptides may often be weaker than that of phenol or m-cresol (phenols). This is an important point to consider when formulating proteins or peptides which have a strong attractive self-interaction potential, making benzyl alcohol an attractive preservative option in such formulations. On the other hand, since the antimicrobial efficacy of preservatives can decrease at high peptide concentration formulations, their concentration subsequently needs to be higher in order to fulfill the antimicrobial efficacy requirements of pharmacopoeias. Consequently, this may subject patients to larger preservative doses. This can be a problem for example in formulations containing benzyl alcohol, since its use should be limited in pediatric patient groups and a higher dose might lead to a higher prevalence of potentially fatal side-effects in neonates. Understanding and possibly controlling the interaction is therefore of paramount importance.

\section{ACKNOWLEDGMENTS AND DISCLOSURES}

The authors wish to acknowledge Claudia Bleyer and Olivier Ortschitt (F. Hoffmann - La Roche Ltd.) for their work with preservative content analyses, Dr. Arne Rufer for his work with AUC analyses, Dr. Sonoko Kanai and Michaela Grass (F. Hoffmann - La Roche Ltd.) for participating in the light scattering experiments and Jenny Train and Anita De Vivo (F. Hoffmann - La Roche Ltd.) for their assistance in manufacturing the sterile formulations for antimicrobial efficacy studies. Furthermore, Dr. Kishore Ravuri (F. Hoffmann - La Roche Ltd.) is acknowledged for his participation in experimental planning and Dr. Sulabh Patel and Tobias Werk (F. Hoffmann - La Roche Ltd.) for their input in interpreting the AET results. Finally, we would also like to acknowledge Prof.Jörg Huwyler (University of Basel, Switzerland) for reviewing this manuscript.

\section{REFERENCES}

1. United States Pharmacopoeia, USP $<51>$ Antimicrobial effectiveness testing. Rockville.

2. European Pharmacopoeia, Ph. Eur. <5.1.3.> Efficacy of antimicrobial preservatives. Strasbourg.

3. Japanese Pharmacopoeia, JP $<19>$ Preservative-effectiveness tests. Tokyo.

4. Meyer B, Ni A, Binghua $\mathrm{H}$, Shi L. Antimicrobial preservative use in parenteral products: past and present. J Pharm Sci. 2007;96(12): 3155-67.

5. Lam X, Patapoff T, Nguyen T. The effect of benzyl alcohol on recombinant human interferon- $\gamma$. Pharm Res. 1997;14(6):725-9.

6. Gupta S, Kaiseva E. Development of a multidose formulation for a humanized monoclonal antibody using experimental design techniques. AAPS Pharm Sci. 2003;5(8):1-9.

7. Bis R, Mallela K. Antimicrobial preservatives induce aggregation of interferon alpha-2a: the order in which preservatives induce protein aggregation is independent of the protein. Int J Pharm. 2014;472: 356-61. 
8. Wolff T, Youngman R. Oxidative metabolism of phenols: conversion of bromochatechol to protein binding species by $\mathrm{O}_{2}{ }^{-}$. In: Bors W, Saran M, Tait D, editors. Oxygen radicals in chemistry and biology. Berlin: Walter de Gruyter and Co; 1984. p. 165-70.

9. Maa Y-F, Hsu C. Aggregation of recombinant human growth hormone induced by phenolic compounds. Int J Pharm. 1996;140: $155-68$.

10. Hutchings R, Singh S, Cabello-Villegas J, Mallela K. Effect of antimicrobial preservatives on partial protein unfolding and aggregation. J Pharm Sci. 2013;102(2):365-76.

11. Whittingham J, Edwards D, Antson A, Clarkson J, Dodson G. Interactions of phenol and $\mathrm{m}$-cresol in the insulin hexamer, and their effects on the association properties of B28 Pro $\rightarrow$ Asp insulin analogues. Biochem. 1998;37(33):11516-23.

12. Swegat W, Schlitter J, Krüger P, Wollmer A. MD simulation of protein-ligand interaction: formation and dissociation of an insulinphenol complex. Biophys J. 2003;84:1493-506.

13. Alford J, Fowler A, Wuttke D, Kerwin B, Latypov R, Carpenter J, et al. Effect of benzyl alcohol on recombinant human interleukin-1 receptor antagonist structure and hydrogen-deuterium exchange. J Pharm Sci. 201 1;100(10):4215-24.

14. Loomis W. Overcoming problems of phenolics and quinones in the isolation of plant enzymes and organelles. Methods Enzymol. 1974;31(A):528-44.

15. Roy S, Katayama D, Dong A, Kerwin B, Randolph T, Carpenter J. Temperature dependence of benzyl alcohol- and 8anilinonaphtalene-1-sulfonate-induced aggregation of recombinant human interleukin-1 receptor antagonist. Biochem. 2006;45(12): 3898-911.

16. Rahuel-Clermont S, French C, Kaarsholm N, Dunn M, Chou C. Mechanisms of stabilization of the insulin hexamer through allosteric ligand interactions. Biochem. 1997;36(19):5837-45.

17. Goyal M, Roy I, Banerjee U, Sharma V, Bansal A. Role of benzyl alcohol in the prevention of heat-induced aggregation and inactivation of hen egg lysozyme. Eur J Pharm Biopharm. 2009;71:36776.

18. Goyal M, Roy I, Amin A, Banerjee U, Bansal A. Stabilization of lysozyme by benzyl alcohol: surface tension and thermodynamic parameters. J Pharm Sci. 2010;99(10):4149-61.
19. Some D, Kendrick S. Characterization of protein-protein interactions via static and dynamic light scattering. In: Cai J, Wang R, editors. Protein interactions. Vienna: InTech; 2013. p. 401-26.

20. Attri A, Minton A. New methods for measuring macromolecular interactions in solution via static light scattering: basic methodology and application to nonassociating and self-associating proteins. Anal Biochem. 2005;337:103-10.

21. Wu D, Chen A, Johnson C. An Improved diffusion-ordered spectroscopy experiment incorporating bipolar-gradient pulses. J Magn Reson A. 1995;115:260-4.

22. Stejskal E, Tanner J. Spin diffusion measurements: spin echoes in the presence of a time-dependent field gradient. J Chem Phys. 1965;42:288-92.

23. Strøm A, Kaasen I. Trehalose metabolism in Escherichia coli: stress protection and stress regulation of gene expression. Mol Microbiol. 1993;8(2):205-10.

24. Wilson J, Lyall J, McBride R, Murray J, Smith G. Partition coefficients of some aromatic alcohols in an n-heptane/water system and their relationship to minimum inhibitory concentration against pseudomonas aeruginosa and staphylococcus aureus. J Clin Hosp Pharm. 1981;6:63-6.

25. Sangster J. Octanol - water partition coefficients of simple organic compounds. J Phys Chem Ref Data. 1989;13(3):1111-227.

26. Pisano F, Kostenbauder H. Interaction of preservatives with macromolecules II: correlation of binding data with required preservative concentrations of p-hydroxybenzoates in the presence of Tween 80. J Am Pharm Assoc. 1957;48(6):310-4.

27. Blanchard J, Fink W, Duffy J. Effect of sorbitol on interaction of phenolic preservatives with polysorbate 80 . J Pharm Sci. 1977;66(10):1470-3.

28. Pinholt C, Kapp S, Bukrinsky J, Hostrup S, Frokjaer S, Norde W, et al. Influence of acylation on the adsorption of GLP-2 to hydrophobic surfaces. Int J Pharm. 2013;440:63-71.

29. Hagerman A, Butler L. The specificity of proanthocyanidin-protein interactions. J Biolog Chem. 1981;256(9):4494-7.

30. Charlton A, Baxter N, Khan M, Moir A, Haslam E, Davies A, et al. Polyphenol/peptide binding and precipitation.J Agric Food Chem. 2002;50:1593-601. 